\title{
Health hazards of fire fighters: exposure assessment
}

\author{
P W BRANDT-RAUF, ${ }^{1}$ L F FALLON JR, ${ }^{1}$ T TARANTINI, ${ }^{2}$ CATHY IDEMA, ${ }^{2}$ \\ L ANDREWS'
}

From the Division of Environmental Sciences, ${ }^{\prime}$ School of Public Health, Columbia University, New York, NY 10032, and Tarantini Associates Ltd, ${ }^{2}$ New York, NY 10012, USA

\begin{abstract}
There is growing concern over the detrimental health effects to firefighters produced by exposure to combustion byproducts of burning materials. To assess the types and levels of exposure encountered by firefighters during their routine occupational duties, members of the Buffalo Fire Department were monitored during firefighting activities with personal, portable, ambient environmental sampling devices. The results indicate that firefighters are frequently exposed to significant concentrations of hazardous materials including carbon monoxide, benzene, sulphur dioxide, hydrogen cyanide, aldehydes, hydrogen chloride, dichlorofluoromethane, and particulates. Furthermore, in many cases of the worst exposure to these materials respiratory protective equipment was not used owing to the visual impression of low smoke intensity, and thus these levels represent actual direct exposure of the firefighters. Many of these materials have been implicated in the production of cardiovascular, respiratory, or neoplastic diseases, which may provide an explanation for the alleged increased risk for these illnesses among firefighters.
\end{abstract}

In recent years there has been increasing concern over the health hazards to firefighters from inhalation of the toxic components of smoke, particularly in the light of the increasing use of synthetic chemical based products in building construction. ${ }^{1}$ This concern has been compounded by mortality and morbidity studies of firefighters, which, although they have produced inconsistent evidence, have at least raised the possibility of increased risks from cardiovascular disease, respiratory disease, and cancer of the nervous system, haematopoietic/lymphatic system, and respiratory and gastrointestinal systems, which may be referable to exposures to components of smoke. ${ }^{1-17}$

Clearly many toxic chemical compounds may be generated and released during fires and these may vary from fire to fire.' Many variables control the resulting byproducts of combustion, the most important being the composition of the burning material. ${ }^{18}{ }^{19}$ Other key factors include the temperature at which pyrolysis or combustion occurs, the concentration of oxygen present, and the efficiency of combustion. ${ }^{18} 19$ Burning materials containing nitrogen, sulphur, and halogens in the presence of carbon and hydrogen can form hydrogen cyanide, nitrogen oxides, sulphur dioxide, ammonia, and halogen acids. ${ }^{20-22}$ Incomplete combustion may result in the formation of hydrocarbons, aldehydes, and particulates. ${ }^{20-22}$ Silk, polyvinyl chloride, wool, household plastics, and insulation Accepted 7 September 1987 materials may produce such toxic byproducts as hydrogen chloride, ammonia, hydrogen fluoride, hydrogen bromide, hydrogen cyanide, isocyanates, and acrolein. ${ }^{22}$

Several previous studies of exposures of firefighters have shown that several of these potentially hazardous byproducts of combustion are encountered during the normal occupational activities of firefighters. Gold $e t$ al studied two units of the Boston Fire Department and identified four atmospheric components that represented serious health hazards: carbon monoxide, hydrogen cyanide, hydrogen chloride, and particulates. ${ }^{23}$ Trietman et al found potentially harmful concentrations of carbon monoxide and acrolein in a study of industrial structure fires in Boston. ${ }^{24}$ They also reported the presence of hydrogen chloride, hydrogen cyanide, benzene, nitrogen dioxide, and carbon dioxide. ${ }^{24}$ Lowry et al have investigated the toxicity of free radical compounds produced in the early phases of a fire. ${ }^{25}$ They monitored exposures of Dallas firefighters and found formaldehyde and the organic products of free radical reactions in addition to the pollutants identified by the previous authors. ${ }^{26}$ The results of these studies are summarised in table 1 and they confirm the suspicion that firefighters may be routinely exposed to toxic materials during the course of their activities.

The current investigation is a continuing study of selected Buffalo, New York, firefighters attempting to 
Table 1 Reported concentration ranges for combustion byproducts at fire sites

\begin{tabular}{|c|c|c|c|}
\hline \multirow{3}{*}{$\begin{array}{l}\text { Material } \\
\text { Carbon monoxide } \\
\text { Hydrogen chloride } \\
\text { Hydrogen cyanide } \\
\text { Formaldehyde } \\
\text { acetaldehyde }\end{array}$} & \multicolumn{3}{|l|}{ Reference } \\
\hline & \multirow{2}{*}{$\begin{array}{c}{\text { Gold et } \text { al }^{23}} \\
3-1000 \\
18-150 \\
0 \cdot 02-5\end{array}$} & \multicolumn{2}{|c|}{ Treitman et al ${ }^{24}$ Lowry et al ${ }^{26}$} \\
\hline & & $\begin{array}{c}15-5000 \\
1-200 \\
0 \cdot 1-5\end{array}$ & $\begin{array}{l}0-15000 \\
0-40 \\
0-40\end{array}$ \\
\hline $\begin{array}{l}\text { Formaldehyde } \\
\text { acetaldehyde } \\
\text { Nitrogen dioxide } \\
\text { Carbon dioxide } \\
\text { Benzene } \\
\text { Particulates }\end{array}$ & $\begin{array}{l}\text { NA } \\
0.02-0.89 \\
\text { NA } \\
\text { NA } \\
4-750\end{array}$ & $\begin{array}{c}\text { NA } \\
0 \cdot 2-10 \\
1000-60000 \\
0 \cdot 2-150 \\
20-20000\end{array}$ & $\begin{array}{l}\mathrm{NA}^{1-15} \\
\mathrm{NA} \\
500^{-1200^{*}} \\
\text { NA }\end{array}$ \\
\hline
\end{tabular}

All concentrations in ppm except particulates which are in $\mathrm{mg} / \mathrm{m}^{3}$.

* Reported as total hydrocarbons.

NA $=$ Not available.

correlate exposures to toxic components of smoke with health outcomes in order to develop recommendations for the reduction of exposure and an improvement in the health of firefighters. This initial report is on exposure assessment, exploring the feasibility of the methodology and equipment for monitoring and identifying the air contaminants in fires that represent potential health hazards for these firefighters. Reviews of the health data on these firefighters and their mortality experience will be the subjects of subsequent reports.

\section{Methods}

Two Buffalo, New York, firehouses were selected for study initially. Fire department statistics were reviewed in 1984 and in that year the department responded to over 11000 calls to fires. The selected firehouses were representative of the department in terms of types of fire, number of casualties, and timing of fires. In addition, they were the two most active firehouses handling approximately $25 \%$ of the city's total calls in 1984. The greatest number of fire incidents occurred in January. Thus a ten day period in January, 1986, was selected during which to conduct the initial study.

About 100 professional firefighters in five fire companies were assigned to the two firehouses studied and 77 volunteered to take part in the medical surveillance programme. These individuals were given a baseline medical examination. They were then available to wear a sampling pump as part of the environmental monitoring programme. A total of 51 firefighters actually participated in this part of the study, the remaining 24 being unavailable during the study period owing to holidays or illness.

The sampling pumps used for the study were from Gilian Instruments, Inc, and combined high and low flow pumping systems. They are portable, battery powered units that draw air at a fixed rate either by maintaining constant flow for high flow (>500 cc/

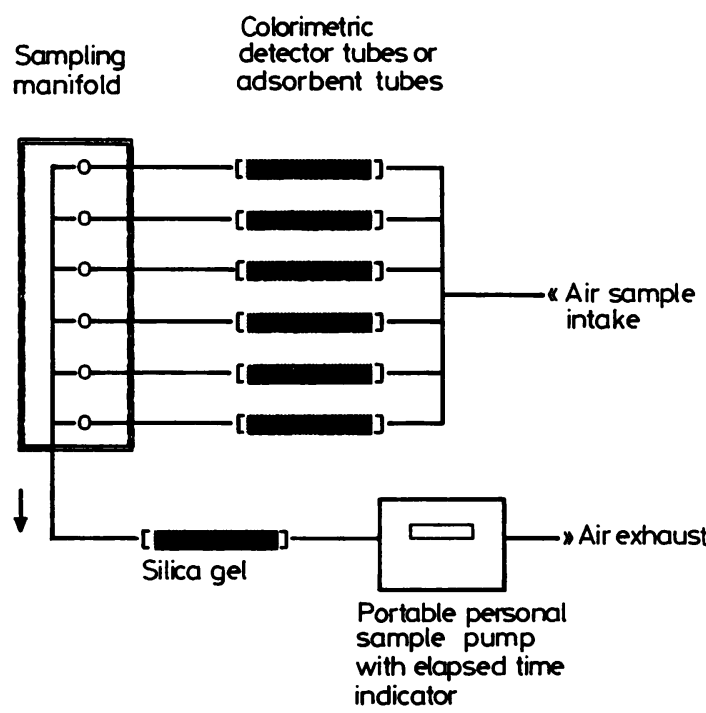

Schematic diagram of sampling pump with six stage variable orifice manifold and tube holder system carried by firefighters for personal ambient environmental monitoring during fires.

min) or through constant pressure regulated by a variable orifice for low flow $(1-500 \mathrm{cc} / \mathrm{min})$. They include a programmable timer that can be used to start and stop the pump at preset intervals and a display timer to indicate total time of operation. The flow rate of the unit is calibrated by using a calibrated flow meter.

A six stage variable orifice manifold and tube holder system for drawing air through the selected colorimetric and charcoal tubes was manufactured by Gilian Instruments, Inc, specifically for this study. It is a portable modification of a non-portable unit described by King $e \mathrm{al}^{27}$ and is shown schematically in the figure. The orifice provides a system for taking multiple samples simultaneously while maintaining an individual flow rate for each sample tube. The tube holders are made of clear plastic with " $O$ " rings at each end to provide a positive seal yet allow visual inspection while the tubes are in place.

The sampling pump and manifold system is placed in a nylon carrier pack and attached to a spanner belt or worn with shoulder or waist straps or both. The unit may be worn over or under normal protective gear. Carrier packs are individually numbered but otherwise identical. A tube extends from the pack to the breathing zone where it is attached by clip to the firefighter's turnout gear. Thus personal exposure air samples were collected from the breathing zone of firefighters during their response to fire incidents. Samples were collected during various stages of firefighter activities (rescue, fire control, overhaul). If respiratory protective equipment was being worn 
samples were collected outside the face pieces. The samples collected thus represented the potential inhalation exposure of the firefighters not wearing respiratory protection.

Colorimetric detector tubes manufactured by Drager, Inc, were used in the pump manifold system to detect the presence of six compounds: carbon monoxide, hydrogen chloride, hydrogen cyanide, sulphur dioxide, benzene, and formaldehyde. In addition to the colorimetric tubes, charcoal sorbent tubes were used to sample organic compounds present in the combustion environment; these tubes were desorbed after exposure and analysed by gas chromatography/ mass spectrometry (GC/MS) methodology. Also, cassettes containing $37 \mathrm{~mm}$ glass fibre filters were used to sample particulate matter encountered during firefighting activities; these were analysed for total particulates by weight before and after exposure. Ambient temperatures in the firefighters' occupational environment were monitored by using Thermotech T-500 temperature sensitive colour detector strips. The strips have colour indicators that turn black at predetermined temperatures. These strips were placed on the exterior of carrier packs or mounted on randonly selected firefighters' helmets.

Ten sampling units, five in each firehouse, were used in the study. Each sample manifold was calibrated before the study. Each variable orifice was individually adjusted and checked against a calibrated flow meter. This procedure was repeated after each use and whenever tubes were replaced. The units were dis- tributed to individual firefighters at the beginning of each shift. In each firehouse the engine and rescue companies each received two units while the ladder company was given one. Individual firefighters turned on their pumps as they arrived at the scene of the fire. The pumps were checked for proper operation during use, typically when a firefighter returned to change self contained breathing apparatus bottles or to pick up equipment. If 30 minutes had elapsed the monitoring package was removed. The monitoring units were returned to each firehouse at the conclusion of the sampling period and all tubes and cassettes were changed. Information was recorded on the time, date, and location of the fire, the company and firefighter responding to the incident, type of monitoring equipment worn, activity performed, characteristics of the fire, and the sampling time elapsed. Temperature strips were inspected for colour change. Colorimetric tubes were inspected for stain; if stain was present the contaminant concentration was determined from the total volume of air sampled based on flow rate and sampling duration. Charcoal sorbent tubes and particulate filters were sealed and labelled with associated volumetric flow rate and sample time recorded; as indicated these were analysed subsequently by $\mathrm{GC} /$ MS and gravimetric techniques, respectively.

\section{Results}

Environmental monitoring was conducted from 8 to 17 January 1986. During this period, 106 calls were

Table 2 Summary of fire characteristics

\begin{tabular}{|c|c|c|c|c|c|}
\hline $\begin{array}{l}\text { Sample } \\
\text { No }\end{array}$ & $\begin{array}{l}\text { Call } \\
\text { No }\end{array}$ & $\begin{array}{l}\text { Structural } \\
\text { material }\end{array}$ & Material burning & $\begin{array}{l}S C B A \\
\text { used }\end{array}$ & $\begin{array}{l}\text { Smoke } \\
\text { intensity }\end{array}$ \\
\hline $\begin{array}{r}1 \\
2 \\
3 \\
4 \\
5 \\
6 \\
7 \\
8 \\
9 \\
10 \\
11 \\
12 \\
13 \\
14 \\
15 \\
16 \\
17 \\
18 \\
19 \\
20 \\
21 \\
22 \\
23 \\
24 \\
25 \\
26\end{array}$ & $\begin{array}{r}1 \\
2 \\
3 \\
4 \\
5 \\
6 \\
7 \\
8 \\
9 \\
10 \\
11\end{array}$ & $\begin{array}{l}\text { Brick/wood } \\
\text { Brick/wood } \\
\text { Concrete } \\
\text { Concrete } \\
\text { Wood } \\
\text { Wood } \\
\text { Wood } \\
\text { Wood } \\
\text { Brick/wood } \\
\text { Wood } \\
\text { Wood } \\
\text { Wood } \\
\text { NA } \\
\text { Wood } \\
\text { Wood } \\
\text { Wood } \\
\text { Wood } \\
\text { Wood } \\
\text { Wood } \\
\text { Wood } \\
\text { Wood } \\
\text { Wood } \\
\text { Wood } \\
\text { NA } \\
\text { NA } \\
\text { Wood }\end{array}$ & $\begin{array}{l}\text { Contents only } \\
\text { Contents only } \\
\text { Contents only } \\
\text { Contents only } \\
\text { Building \& contents } \\
\text { Building \& contents } \\
\text { Building \& contents } \\
\text { NA } \\
\text { Building only } \\
\text { Contents only } \\
\text { Building \& contents } \\
\text { Building \& contents } \\
\text { NA } \\
\text { Building \& contents } \\
\text { Building \& contents } \\
\text { Building \& contents } \\
\text { Building \& contents } \\
\text { Building \& contents } \\
\text { Building \& contents } \\
\text { Building \& contents } \\
\text { Building \& contents } \\
\text { Building \& contents } \\
\text { Building \& contents } \\
\text { Car } \\
\text { Car } \\
\text { Building \& contents }\end{array}$ & $\begin{array}{l}\text { No } \\
\text { No } \\
\text { Yes } \\
\text { Yes } \\
\text { Partial } \\
\text { Partial } \\
\text { Yes } \\
\text { Partial } \\
\text { Yes } \\
\text { No } \\
\text { Partial } \\
\text { Partial } \\
\text { No } \\
\text { Yes } \\
\text { No } \\
\text { Partial } \\
\text { Yes } \\
\text { Yes } \\
\text { Yes } \\
\text { Yes } \\
\text { Yes } \\
\text { No } \\
\text { Yes } \\
\text { No } \\
\text { No } \\
\text { Partial }\end{array}$ & $\begin{array}{l}\text { Low } \\
\text { Low } \\
\text { Moderate } \\
\text { Intolerable } \\
\text { Moderate } \\
\text { Moderate } \\
\text { High } \\
\text { Moderate } \\
\text { NA } \\
\text { Low } \\
\text { Low } \\
\text { Moderate } \\
\text { Low } \\
\text { None } \\
\text { Low } \\
\text { Low } \\
\text { Intolerable } \\
\text { Intolerable } \\
\text { Low } \\
\text { Intolerable } \\
\text { Moderate } \\
\text { Low } \\
\text { Moderate } \\
\text { Low } \\
\text { Low } \\
\text { Intolerable }\end{array}$ \\
\hline
\end{tabular}


Table 3 Colorimetric detector tube sampling results

\begin{tabular}{|c|c|c|c|c|c|c|c|}
\hline $\begin{array}{l}\text { Sample } \\
\text { No }\end{array}$ & $\begin{array}{l}\text { Call } \\
\text { No }\end{array}$ & $\begin{array}{l}\text { Carbon } \\
\text { monoxide }\end{array}$ & $\begin{array}{l}\text { Hydrogen } \\
\text { chloride }\end{array}$ & $\begin{array}{l}\text { Hydrogen } \\
\text { cyanide }\end{array}$ & $\begin{array}{l}\text { Sulphur } \\
\text { dioxide }\end{array}$ & Benzene & Formaldehyde \\
\hline 1 & 1 & $41 \cdot 7$ & 0 & 0 & 0 & 0 & 0 \\
\hline 2 & & $41 \cdot 6$ & 0 & 0 & 0 & 0 & 0 \\
\hline 3 & 2 & 800 & $13 \cdot 3$ & 0 & $1 \cdot 7$ & $8 \cdot 3$ & $3 \cdot 3$ \\
\hline 4 & & 250 & NA & 75 & $41 \cdot 7$ & $158 \cdot 3$ & NA \\
\hline 5 & 3 & $16 \cdot 6$ & 0 & 0 & 0 & 0 & 0 \\
\hline 6 & & 150 & 0 & $2 \cdot 5$ & $1 \cdot 7$ & $83 \cdot 3$ & 0 \\
\hline 8 & & $33 \cdot 3$ & 0 & 0.8 & 0.4 & $16 \cdot 6$ & 0 \\
\hline 9 & 5 & 250 & 0 & 10 & $2 \cdot 5$ & 250 & 0 \\
\hline 10 & 6 & $41 \cdot 7$ & 0 & 0 & 0 & $41 \cdot 7$ & 0 \\
\hline 11 & 7 & 100 & 0 & 0 & 0.2 & $54 \cdot 2$ & 0 \\
\hline 12 & & 25 & 0 & 0 & 0 & 0 & 0 \\
\hline 13 & 8 & 100 & 0 & 0 & 0 & NA & 0 \\
\hline 14 & 9 & $483 \cdot 3$ & 0 & 10 & $2 \cdot 5$ & 166.7 & 0.4 \\
\hline 15 & & 166.7 & NA & 5 & $2 \cdot 5$ & $29 \cdot 2$ & 0.8 \\
\hline 16 & 10 & 62.5 & 0 & 0 & 0 & 50 & 0 \\
\hline 18 & & 333.3 & NA & 0 & 0 & 0 & 0 \\
\hline 19 & & 18.5 & NA & 0 & 0 & 0 & 0 \\
\hline 20 & 12 & $833 \cdot 3$ & 0 & $6 \cdot 7$ & $1 \cdot 7$ & $33 \cdot 3$ & 0.4 \\
\hline 21 & & $41 \cdot 7$ & NA & 0 & 0 & 50 & 0 \\
\hline 22 & & 17 & 0 & 0 & 0 & 0 & NA \\
\hline 23 & & 833.3 & NA & $4 \cdot 2$ & $1 \cdot 7$ & 25 & 0.1 \\
\hline 24 & 13 & 11.4 & NA & 0 & 0 & $34 \cdot 1$ & 0 \\
\hline 25 & & $34 \cdot 1$ & 0 & 0 & 0 & $22 \cdot 7$ & 0 \\
\hline 26 & 14 & 1087 & $2 \cdot 17$ & $8 \cdot 7$ & $1 \cdot 1$ & 10.9 & 0 \\
\hline
\end{tabular}

All concentrations in ppm.

received at the two firehouses. Fourteen calls were of sufficient duration and magnitude to permit monitoring. These included fires in residential structures, industrial buildings, and a car. A total of 26 usable samples was collected. Table 2 presents the salient characteristics of the fires: type, materials burning, estimates of smoke intensity, and use of respiratory protective equipment.

The results of the sampling analyses for the specific detector tubes, charcoal sorbent tubes, and particulate filters are presented in tables 3-5, respectively. Carbon monoxide was found to be present in all 14 fires sampled. The concentrations ranged from 11.4 to 1087 parts per million (ppm), with $73 \%$ of the values above the NIOSH recommended eight hour time weighted average threshold limit value (TLV-TWA) of $35 \mathrm{ppm}$, $55 \%$ of the values above the OSHA permissible exposure limit (PEL) and ACGIH TLV-TWA of $50 \mathrm{ppm}, 38 \%$ of the values above the NIOSH recommended ceiling concentration of $200 \mathrm{ppm}$, and $19 \%$ of the values above the ACGIH short term exposure limit (TLV-STEL) of $400 \mathrm{ppm}^{2829}$

The second most prevalent chemical was benzene which was present in 12 of the 14 fires monitored. Concentrations ranged from 8.3 to $250 \mathrm{ppm}$, all being appreciably higher than the NIOSH recommended and OSHA proposed exposure level of $1 \mathrm{ppm}$, with $94 \%$ of the values above the OSHA PEL and ACGIH TLV-TWA of $10 \mathrm{ppm}, 78 \%$ of the values above the OSHA acceptable ceiling concentration and ACGIH TLV-STEL of $25 \mathrm{ppm}$, and $50 \%$ of the values above the OSHA 10 minute acceptable maximum peak of 50 ppm. ${ }^{28} 29$

Sulphur dioxide was present in more than half $(8$ incidents) the fire environments sampled. Concentrations ranged from 0.2 to $41.7 \mathrm{ppm}$ with $42 \%$ of the values above the NIOSH/ACGIH TLV-TWA of $2 \mathrm{ppm}$; the maximum concentration was well in excess of the OSHA PEL of 5 ppm. ${ }^{28} 29$

Hydrogen cyanide was also detected in eight of the

Table 4 Charcoal sorbent tube sampling results

\begin{tabular}{|c|c|c|c|c|c|c|c|}
\hline $\begin{array}{l}\text { Call } \\
\text { No }\end{array}$ & $\begin{array}{l}\text { Dichlorofluoro- } \\
\text { methane }\end{array}$ & $\begin{array}{l}\text { Methylene } \\
\text { chloride }\end{array}$ & $\begin{array}{l}\text { Trichloro- } \\
\text { ethylene }\end{array}$ & Chloroform & $\begin{array}{l}\text { Perchloro- } \\
\text { ethylene }\end{array}$ & Toluene & $\begin{array}{l}\text { Trichloro- } \\
\text { phenol }\end{array}$ \\
\hline $\begin{array}{r}9 \\
11 \\
12 \\
12 \\
13\end{array}$ & $\begin{array}{c}0.67 \\
4.93 \\
10.1 \\
12.1 \\
1.65\end{array}$ & $\begin{array}{l}\text { NA } \\
\text { NA } \\
\text { NA } \\
0 \cdot 278 \\
\text { NA }\end{array}$ & $\begin{array}{l}0.112 \\
\text { NA } \\
\text { NA } \\
0 \cdot 181 \\
\text { NA }\end{array}$ & $\begin{array}{l}0.960 \\
\text { NA } \\
\text { NA } \\
1.92 \\
\text { NA }\end{array}$ & $\begin{array}{l}0.064 \\
\text { NA } \\
0.138 \\
0.074 \\
\text { NA }\end{array}$ & $\begin{array}{l}0.160 \\
\text { NA } \\
0 \cdot 275 \\
0 \cdot 248 \\
\text { NA }\end{array}$ & $\begin{array}{l}\text { NA } \\
\text { NA } \\
\text { NA } \\
0 \cdot 129 \\
\text { NA }\end{array}$ \\
\hline
\end{tabular}

All concentrations in ppm. 
Table 5 Particulate filter sampling results

\begin{tabular}{lc}
\hline Call No & Particulate concentration $\left(\mathrm{mg} / \mathrm{m}^{3}\right)$ \\
\hline 6 & $10 \cdot 39$ \\
8 & $10 \cdot 80$ \\
9 & $344 \cdot 4$ \\
12 & $10 \cdot 1$ \\
13 & $38 \cdot 3$ \\
\hline
\end{tabular}

14 fires. All but the highest concentration recorded were at or below the ACGIH ceiling limit and OSHA PEL of $10 \mathrm{ppm}$; however, the maximum concentration (75 ppm) exceeded the immediately dangerous to life and health (IDLH) value (50 ppm) by $50 \%$. ${ }^{28-30}$

The presence of formaldehyde (and other interfering aldehydes such as acrolein and acetaldehyde) was detected in only four fires. Concentrations ranged from $0 \cdot 1$ to $8.3 \mathrm{ppm}$ with two values $(3.3$ and $8.3 \mathrm{ppm}$ ) above the NIOSH/ACGIH TLV-TWA of $1 \mathrm{ppm}$ and the current OSHA PEL of $3 \mathrm{ppm}$; the highest value is also above the OSHA acceptable ceiling concentration of 5 ppm. ${ }^{28} 29$

Only two fires produced hydrogen chloride in detectable quantities. One value (13.3 ppm) exceeded the OSHA/ACGIH acceptble ceiling limit of $5 \mathrm{ppm}^{2829}$

Four fires yielded five usable charcoal sorbent tube samples. GC/MS analysis showed dichlorofluoromethane to be the most prevalent compound appearing in every sample; in two samples it exceeded the ACGIH TLV-TWA of $10 \mathrm{ppm} .{ }^{29}$ Other detectable compounds of interest included trichloroethylene, perchloroethylene, chloroform, methylene chloride, toluene, and trichlorophenol. All were present at quite low concentrations as indicated, although one concentration of chloroform $(1.92 \mathrm{ppm})$ approached the NIOSH recommended exposure limit of $2 \mathrm{ppm}^{28}$

Five glass fibre filtered particulate samples were obtained. Concentrations ranged from $10 \cdot 1$ to $344.4 \mathrm{mg} /{ }^{3}$, all exceeding the ACGIH TLV-TWA for nuisance particulates of $10 \mathrm{ppm}^{29}$

Heat monitoring results using the temperature sensitive colour detector strips showed that all temperatures encountered were less than $200^{\circ} \mathrm{F}$, the minimum detection limit of these strips.

\section{Discussion}

The results confirm the impression of previous studies that several potentially toxic compounds at various concentrations are present in the firefighting environment and are encountered by firefighters during their responses to routine fire incidents. The variety of toxins detected is particularly disturbing considering the limited number and types of fires studied; 14 fires over a 10 day period were sampled, and most of these were in residential structures composed primarily of wood or brick, or both, common building materials widely used throughout the country.

Carbon monoxide was widely encountered as expected, but surprisingly so was benzene at appreciable concentrations plus a wide variety of other organics at much lower concentrations as described, despite the limited nature of the fires studied as noted. Carbon monoxide and benzene when present were usually well in excess of the eight hour TLV-TWA. All particulate samples exceeded the TLV and one recorded value of hydrogen cyanide considerably exceeded the IDLH value. It is granted that comparison of these exposure levels to eight hour TLV-TWA values may be misleading, since most firefighting activities are not continuous over an eight hour period, although at busy firehouses such as these, activities with exposure could occupy considerable portions of a given shift; studies over longer periods will be necessary to clarify the relation of these exposures to the more traditional TLV values.

The limitations of the technology used in this study must be recognised. Colorimetric detector tubes were selected because they are inexpensive and easy to use and thus would lend themselves to large scale use on a routine basis. These tubes, however, have problems with specificity and accuracy. Regarding specificity, the reaction mechanisms used for various tubes will rarely be restricted to only one substance. Although the manufacturers have tested for and reported the influence of common interfering substances on specific tubes, not all possible interferences have been tested. Considering the chemical mixture that is obviously emitted from a fire, it is quite possible that the length of colour stain developed on any given colorimetric tube will reflect the reaction of not only the contaminant of interest but also the effect of both positive and negative interferences from co-contaminants in the same environment. In general, positive interferences are more likely than negative ones. Thus it is possible that the concentrations of some of the contaminants reported on the basis of the colorimetric tubes are biased high. This was a known problem, for example, with the formaldehyde tube detection since other aldehydes that could be present in fires (acrolein, acetaldehyde) would be detected.

Secondly, colorimetric detector tubes are not very accurate even under ideal conditions (approximately $25 \%$ of the tube concentration). As a check on this, we compared the concentrations for benzene as determined colorimetrically with that determined by $\mathrm{GC} /$ MS analysis on a charcoal sorbent tube from the same fire (call number 12). Four firefighters in this fire were monitored for benzene using the colorimetric tube method; concentrations of benzene recorded were 0 , 
25,33 , and $50 \mathrm{ppm}$. Another firefighter was monitored during the same incident using the charcoal tube/GC/ MS method and his estimated benzene exposure was about $1 \mathrm{ppm}$. Such a wide discrepancy between the highest and lowest values obtained by the colorimetric technique and between the values determined by the two different techniques may be attributed to many factors. For example, this may merely be indicative of the wide range of non-comparable exposure conditions encountered at any given fire. Nevertheless, it may also reflect the limited accuracy of the colorimetric techniques. In consideration of this and the potential for interferences from other chemicals in the emissions plume as noted above, it is probably best to consider the measured concentrations by colorimetric techniques to be approximations rather than accurate determinations. Future studies with more elaborate back up determinations including more concomitant charcoal sorbent/GC/MS assays will provide a clearer picture of the accuracy of colorimetric assays for routine field monitoring of firefighters.

Glass fibre filters for particulate matter sampling were used in this study because of the advantages they have in terms of high collection capacities over membrane filters. Analysis of the chemical and morphological characteristics of an aerosol, however, are problematic with glass fibre filters because of entrapment within and interferences by trace elements in the glass fibres. In future it will be necessary to rely on membrane filters in addition to obtain a better assessment of the nature of the particulates encountered.

Within the constraints of these limitations this study still serves to indicate that firefighters may be exposed to appreciable concentrations of a range of toxic materials during routine occupational activities. Furthermore, it should be noted that some of the toxins encountered in this study have the potential to produce cardiovascular and respiratory disease and cancer, the illnesses for which firefighters have been suggested to be at increased risk. It may be pointed out that these are only potential exposures since sampling was done in the breathing zone but outside of any respiratory protective equipment. It should also be noted, however, that in several fires respiratory protection was used only partially or not at all (presumably owing to the impression of low smoke intensity); yet it was at these same fires that appreciable concentrations of hazardous materials (particularly carbon monoxide and benzene) were recorded and thus the firefighters were being directly exposed. This observation would argue for more extensive use of respiratory protective equipment by firefighters regardless of the impression of hazard estimated from smoke intensity.

Clearly, further study is necessary. In particular, it will be necessary to validate and expand these results with the methodological changes noted above in a greater diversity of fires over a longer period. Further, it will be desirable to correlate this information on exposure with health outcomes and the morbidity and mortality experience of firefighters. These studies are currently in progress.

This work was made possible by grant $\mathrm{C} 001000 / 85055$ from the New York State Department of State in cooperation with the Association of New York State Professional Firefighters. In addition, one of the authors (LFF) was supported in part by NCI Cancer Epidemiology, Biostatistics and Environmental Sciences training grant 5T32CA09529-02. We express our appreciation to the members of the Buffalo Fire Department, especially Commissioner Albert Duke and his deputy Kenneth Trometta, for their cooperation and help and the Association of New York State Professional Firefighters and the State Fire Administrator Francis A McGarry for their help in organising the study. We also recognise the contributions of $\mathbf{M}$ Barboza and L Militana, Woodward-Clyde consultants; Dr A Aquilina, Erie County Medical Center; Dr J Zizzi, director, Erie County Health Department; Dr O Smith-Blackwell, regional director, New York State Health Department (Western Region); and Dr J Vena, SUNY Buffalo. We are particularly grateful for the efforts of the late Dr Melvin Schwartz who was instrumental in initiating this project.

\section{References}

1 Committee on Fire Toxicology. Fire and smoke: understanding the hazards. Washington: National Academy Press, 1986.

2 Mastromatteo E. Mortality in city firemen, II: a study of mortality in firemen of a city fire department. AMA Arch Ind Health 1959;20:227-33.

3 Barnard RJ, Gardner GW, Diaco NV, et al. Near-maximal ECG stress testing and coronary artery disease risk factor analysis in Los Angeles city firefighters. J Occup Med 1975;17:693-5.

4 Bates JT. Coronary artery disease deaths in the Toronto fire department. J Occup Med 1987;29:132-5.

5 Unger KM, Snow RM, Mestas J, et al. Smoke inhalation in firemen. Thorax 1980;35:838-42.

6 Peabody H. Pulmonary function and the firefighters. Journal of Combustion Toxicology 1977;4:8-15.

7 Peters J, Theriault G, Fine L, et al. Chronic effect of firefighting on pulmonary function. $N$ Engl J Med 1974;291:1320-2.

8 Sparrow D, Bosse R, Rosner B, et al. The effect of occupational exposure on pulmonary function: a longitudinal evaluation of firefighters and non-fighters. Am Rev Respir Dis 1982;125:31922.

9 Douglas DB, Douglas RB, Oakes D, et al. Pulmonary function of London firemen. Br J Ind Med 1985;42:55-8.

10 Sidor R, Peters JM. Prevalence rates of chronic non-specific respiratory disease in fire-fighters. Am Rev Respir Dis 1974;109:255-61.

11 Milham S, Jr. Occupational mortality in Washington State 1950 71. Vol III. Cincinnati; NIOSH Division of Surveillance, Hazard Evaluations, and Field Studies, 1976. (NIOSH 76-175C.)

12 Enterline P, McKiever M. Differential mortality from lung cancer 
by occupation. J Occup Med 1963:5:283-90.

13 Petersen GR, Milham S, Jr. Occupational mortality in the State of California 1959-1961. Cincinnati: NIOSH, 1980. (NIOSH 80104.)

14 Feuer E, Rosenman K. Mortality in police and firefighters in New Jersey. Am J Ind Med 1986;9:517-27.

15 Lewis SS, Bierman HR, Faith MR. Cancer mortality among Los Angeles City firefighters: report to the Los Angeles fire department. Beverly Hills: Institute for Cancer and Blood Research, 1983.

16 Schulte PA, Ehrenberg RL. Health hazard evaluation of the Chester fire department, Chester, Pennsylvania. Cincinnati: NIOSH, 984. (HETA 83-360-1495.)

17 Abrams JL. Occupational mortality among professional firefighters. Oklahoma City: University of Oklahoma, 1974. (Doctoral dissertation.)

18 Terrill JB, Montgomery RR, Reinhardt CF. Toxic gases from fires. Science 1978;200:1343-7.

19 Zapp JA, Jr. The toxicity of fire. Chemical Center, Md: Chemical Corps, Medical Division, 1951. (Special rep No 4.)

20 Boettner EA, Ball G, Weiss B. Analysis of the volatile combustion products of vinyl plastics. Journal of Applied Polymer Science 1969;13:377-95.

21 Montgomery RR, Reinhardt CF, Terrill JB. Combustion tox- icology. Journal of Fire Flammability Combustion Toxicology 1975;2:179-85.

22 Hartzell GE, Packham SC, Switzer WG. Toxic products from fires. Am Ind Hyg Assoc J 1983;44:248-55.

23 Gold A, Burgess WA, Clougherty EV. Exposure of firefighters to toxic air contaminants. Am Ind Hyg Assoc J 1978;39:534-9.

24 Treitman RD, Burgess WA, Gold A. Air contaminants encountered by firefighters. Am Ind Hyg Assoc J 1980;41:796-802.

25 Lowry WT, Peterson J, Petty CS, et al. Free radical production from controlled low-energy fires: toxicity considerations. $J$ Forensic Sci 1985;30:73-85.

26 Lowry WT, Juarez L, Petty CS, et al. Studies of toxic gas production during actual structural fires in the Dallas area. J Forensic Sci 1985;30:59-72.

27 King MV, Eller PM, Costello RJ. A qualitative sampling device for use at hazardous waste sites. Am Ind Hyg Assoc J 1983;44:615-8.

28 Lederer WH, Regulatory chemicals of health and environmental concern. New York: Van Nostrand Reinhold Co, 1985.

29 American Conference of Governmental Industrial Hygienists. Threshold limit values and biological exposure indices for 19861987. Cincinnati: ACGIH, 1986.

30 Clayton GD, Clayton FE. Patty's industrial hygiene and toxicology. New York: John Wiley and Sons, 1982.

\section{Destruction of manuscripts}

From 1 July 1985 articles submitted for publication will not be returned. Authors whose papers are rejected will be advised of the decision and the manuscripts will be kept under security for three months to deal with any inquiries and then destroyed. 